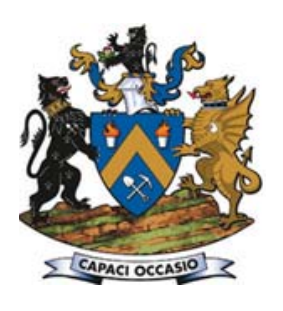

Affiliation:

${ }^{1}$ Engineering Training Center, Wuhan University of Science and Technology, China.

${ }^{2}$ The State Key Laboratory of Refractories and Metallurgy, Wuhan University of Science and Technology, China.

Correspondence to:

C. Liu

Email:

liuchengsong@wust.edu.cn

Dates:

Received: 22 Jan. 2018

Revised: 10 Oct. 2018

Accepted: 24 Oct. 2018

Published: May 2019

\section{How to cite:}

Liu, X., Liu, C., Wang, B., and

Ye, F.

Optimization of iron ore blending in the COREX shaft furnace.

The Southern African Insitute of Mining and Metallurgy

DOI ID:

http://dx.doi.org/10.17159/24119717/18/018/2019

ORCID ID:

X. Liu

https://orchid.org/0000-0002-

0015-5630

C. Liu

https://orchid.org/0000-0002-

0271-693X

B. Wang

https://orchid.org/0000-0002-

2987-7127

F. Ye

https://orchid.org/0000-0001$8521-4451$

\title{
Optimization of iron ore blending in the COREX shaft furnace
}

\author{
X. Liu ${ }^{1}$, C. Liü ${ }^{2}$, B. Wang ${ }^{2}$, and F. Ye ${ }^{2}$
}

\section{Synopsis}

To extend the variety of lump ores that are used in the COREX shaft furnace and to optimize iron ore blending, the original evaluation method for iron ores that was proposed by Voestalpine AG has been improved. Physicochemical and metallurgical properties of iron ores, including Sishen lump ore and CVRD pellets, which are currently used in the COREX process, and three other lump ores, were assessed and compared. Ore matching principles were proposed and five optimized iron ore blending schemes designed and verified by laboratory experiments to prove the effectiveness of the improved evaluation method. The replacement of Sishen lump ore by the alternative L2 and L3 lump ores without varying the proportion of CVRD pellets could improve the degree of reduction and rate of metallization, and decrease the bonding index. Based on the results of laboratory test work and industrial- trials, an ore blending scheme of $60 \% \mathrm{CVRD}, 20 \% \mathrm{~L} 2$, and $20 \% \mathrm{~L} 3$ is recommended for use in the COREX process.

\section{Keywords}

COREX, iron ores, metallurgical properties, blending optimization.

\section{Introduction}

In recent years, problems such as environmental pollution and a shortage of coke and coal resources for blast-furnace ironmaking have become increasingly apparent. Based on sustainable developments in the iron- and steelmaking industries, the environmentally friendly COREX smelting-reduction process with low energy consumption was developed and introduced (Zhou and Du, 2013; Song, Lv, and Yin, 2015; Xu et al., 2016; Kurunov, 2010). The evaluation system for lump ore that was proposed by Voestalpine AG recommends that only Sishen lump ore from South Africa be used in the COREX process, because of the stringent physicochemical and metallurgical property requirements. This situation significantly hampers improvements to the technical and economic aspects of the COREX ironmaking process, especially in China (Eberle, Siuka, and Bohm, 2006). No theoretical or technical basis has been provided for the evaluation system, and the assessment approach for iron ores also presents problems that need to be discussed and resolved.

The COREX process consists of two reactors: the prereduction shaft furnace and the melting gasifier as shown in Figure 1 (Wu et al., 2017). Pellets and lump ores which are charged to the prereduction shaft should have a good reducibility and metallization with a low degradation index (Li et al., 2016; Wu et al., 2011; Kumar et al., 2009; Kang, Gupta, and Sahajwalla, 2007). The properties and microstructure of the iron ore pellets which are required to achieve a high productivity and a lower fuel rate in the COREX process have been investigated (Umadevi et al., 2011). Some efforts have also been made to investigate the behaviour of lump ores in the COREX shaft furnace, including the disintegration characteristics and the reduction degradation (Umadevi et al., 2011; Zhou et al., 2015; Xu et al., 2013; Li, Feng, and Zou, 2013; Hou et al., 2014). However, few studies have focused on the optimization of ore blending for partial or total substitution of the expensive Sishen lump ore by other, cheaper lump ores to reduce the production cost. The technology for the utilization of blended lump ores in the COREX process is still in its early development stages (Zhou et al., 2017; You et al., 2017).

In this work, the original evaluation system for iron ores that was proposed by Voestalpine AG was modified and improved to approach the actual requirements for the production of hot metal in the COREX process. The properties of Sishen lump ore, CVRD pellets, and three alternative lump ores, including chemical compositions, size distribution, amount of adhesive powder, thermal cracking properties, reducibility, and reduction degradation and bonding properties, were investigated and compared. Ore 


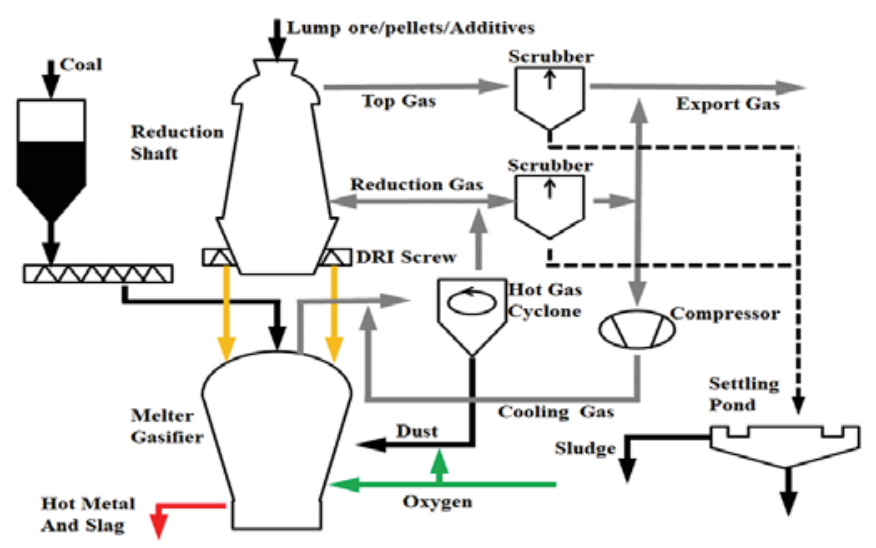

Figure 1-Schematic diagram of the COREX process (Wu et al., 2017)

blending principles are proposed and discussed based on the above physicochemical and metallurgical property results. Five schemes of iron ore blending were designed and verified by laboratory experiments. Finally, the industrial feasibility of the optimal blending scheme was verified through the COREX production practice.

\section{Proposal for the improved evaluation of iron ores}

\section{Supplementary evaluation system}

The original evaluation system as developed by Voestalpine AG targeted the physicochemical characteristics and static reduction properties of iron ores. The former include the chemical composition, size distribution, and bulk density, whereas the latter comprise the reduction degree, reduction degradation, and bonding properties at high temperature. However, according to previous work (Wu et al., 2011), a significant low-temperature reduction degradation of iron ore occurred in experiments and during production, which affected the furnace's smooth operation. Thus it was necessary to incorporate the lowtemperature reduction degradation of iron ore into the evaluation system. In addition, because of thermal stress, thermal cracking probably occurs in the iron ores, especially lump ores, which reduces burden permeability and causes an uneven distribution of gas flow and a low degree of metallization. A measurement of the thermal cracking index should also be taken into account when assessing the properties of iron ores that are used in the COREX process. In addition, in the COREX production process, the large-size lump ores in the charge will gradually break down to small particles and powder due to thermal cracking and lowtemperature reduction degradation during heating. However, before the lump ores are charged into the reduction shaft furnace, a certain amount of original ore powder, which is generated during mining and transportation due to interparticle impact and abrasion, adheres to the lump surfaces. The original ore powder will be charged into the reduction shaft furnace along with the lump ores and affect the permeability of the burden. Therefore, in order to comprehensively and accurately evaluate the properties of the lump ores, the inclusion of adhesive powder with an equivalent diameter below $1.0 \mathrm{~mm}$ is proposed in this study. The amount of adhesive powder was also measured and analysed, and will be further elaborated on later.

\section{Modification of measurement approaches}

\section{Experimental temperature}

In original measurements of the static loading reduction of iron ores, the highest experimental temperature was set at 1073 $\mathrm{K}$, lower than the actual gas temperature, which was in the range 1073-1173 K at the furnace inlet during practical COREX production. In this study, the highest experimental temperature in the modified measurement approach was increased to 1123 $\mathrm{K}$ to study the behaviour of iron ores in the shaft furnace more practicably.

\section{Temperature curve}

During the COREX ironmaking process, the heating and reducing durations at the high temperature are approximately 3 hours and 2 hours, respectively. The original measurement for the static loading reduction of iron ores as proposed by Voestalpine AG requires only 1 hour for the iron ore sample to be heated from room temperature to the highest temperature, with the sample being maintained at that temperature for 5 hours. The temperature curve for the reduction test in this study was modified according to the practical parameters. Initially, the temperature was increased by $5 \mathrm{~K} / \mathrm{min}$ from room temperature to $1123 \mathrm{~K}$, and then maintained for 2 hours. The cooling rate was about $4 \mathrm{~K} / \mathrm{min}$ after power off.

\section{Gas flow rate}

In the original measurement for the static loading reduction of iron ores, the gas flow rate per kilogram of iron ore was $6.7 \mathrm{~L} / \mathrm{min}$, compared with $20 \mathrm{~L} / \mathrm{min}$ during COREX ironmaking production. Therefore, the gas flow rate in the experiments was increased to $20 \mathrm{~L} / \mathrm{min}$ per kilogram of iron ore to simulate production in the revised measurement approach.

The comparison of the current and desired parameters in the reduction test is summarized in Table I.

\section{Physicochemical characteristics of iron ores used in the experiments}

\section{Chemical composition}

Sishen lump ore and CVRD pellets were used initially in the COREX shaft furnaces in China. Alternative lump ores L1, L2, and L3 were imported from Brazil, Australia, and South Africa respectively. The dominant phase in the iron ores was haematite. The chemical compositions of the iron ore samples, measured by X-ray fluorescence spectrometry, are shown in Table II.

\section{Size distribution}

The particle size distributions and average sizes of the iron ore samples are shown in Table III. The CVRD pellets exhibited a narrower particle size distribution and a lower average size, which is beneficial for burden permeability and reduction efficiency. Sishen lump ore had a moderate size-distribution

\section{Table I}

Comparison of the current and desired parameters in the reduction test

\begin{tabular}{|l|c|c|}
\hline Parameter & Current value & Desired value \\
\hline Highest experimental temperature & $1073 \mathrm{~K}$ & $1123 \mathrm{~K}$ \\
Heating time & $1 \mathrm{~h}$ & Approx. $3 \mathrm{~h}$ \\
Reduction time & $5 \mathrm{~h}$ & $2 \mathrm{~h}$ \\
Gas flow rate & $6.7 \mathrm{~L} / \mathrm{min}$ & $20 \mathrm{~L} / \mathrm{min}$ \\
\hline
\end{tabular}




\section{Optimization of iron ore blending in the COREX shaft furnace}

Table II

Chemical composition of iron ore samples (wt\%)

\begin{tabular}{|c|c|c|c|c|c|c|c|c|c|c|}
\hline Sample & $\mathrm{Fe}$ (total) & $\mathrm{CaO}$ & $\mathrm{SiO}_{2}$ & $\mathrm{Al}_{2} \mathrm{O}_{3}$ & $\mathrm{TiO}_{2}$ & $\mathbf{P}$ & $S$ & $\mathrm{~K}_{2} \mathrm{O}$ & $\mathrm{Na}_{2} \mathrm{O}$ & LOI \\
\hline L1 & 65.79 & 0.07 & 2.88 & 1.57 & 0.08 & 0.063 & 0.006 & 0.010 & 0.002 & 1.71 \\
\hline L2 & 64.58 & 0.08 & 3.20 & 1.48 & 0.05 & 0.074 & 0.011 & 0.014 & 0.005 & 2.66 \\
\hline L3 & 65.24 & 0.06 & 3.39 & 1.47 & 0.07 & 0.019 & 0.021 & 0.180 & 0.029 & 0.48 \\
\hline Sishen & 65.94 & 0.07 & 3.22 & 0.76 & 0.03 & 0.041 & 0.018 & 0.050 & 0.003 & 0.61 \\
\hline CVRD & 65.73 & 2.65 & 2.37 & 0.80 & 0.04 & 0.039 & 0.006 & 0.019 & 0.024 & 0.08 \\
\hline
\end{tabular}

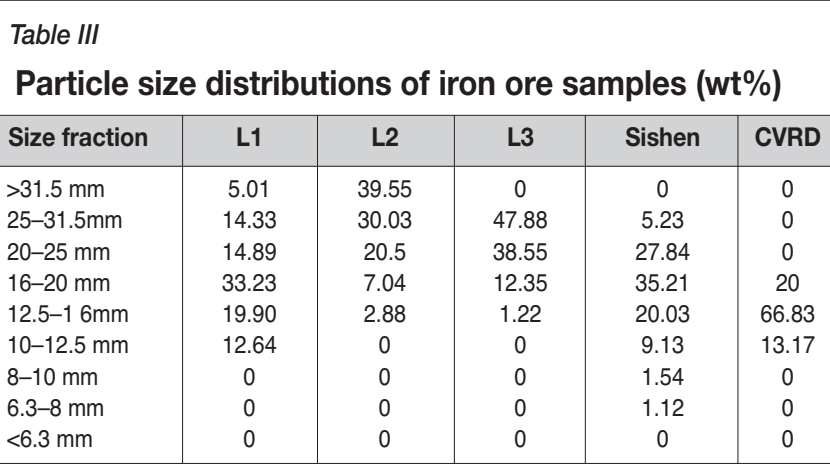

uniformity and average size, whereas L1 lump ore had a relatively broad particle size distribution and a higher average size. For L2 and L3 lump ores, the particle size distributions were better than those of L1 and the Sishen lump ores. Iron ores are probably crushed into powder or small particles during production in the COREX prereduction shaft furnace because of the high pressure, so the larger average sizes of L2 and L3 benefited production.

\section{Amount of adhesive powder}

As indicated before, in the processes of mining and transportation, some ore powder is generated and adheres to the surface of lump ores, which would probably affect the gas flow distribution, burden permeability, and the degree of reduction and metallization rate during COREX production. The amount of adhesive powder was calculated from the weight difference of the iron ore samples before and after brushing. Firstly, $1 \mathrm{~kg}$ portions of the original iron ore samples containing all size fractions were prepared and dried in a box furnace at $373 \pm 5 \mathrm{~K}$ for 12 hours. The samples were then brushed with water, screened at a mesh size of $1 \times 1 \mathrm{~mm}$, dried again at $373 \pm 5 \mathrm{~K}$ for 12 hours, and weighed. The proportion of adhesive powder (PAP) was obtained by Equation [1].

$$
P A P=\frac{W_{0}-W_{1}}{W_{0}} \times 100 \%
$$

where $W_{0}$ is the mass of the original iron ore sample after drying, and $W_{1}$ is the mass of sample (>1 mm) after brushing and drying.

This process was repeated for three times to obtain the average value. The results are shown in Table IV.

\section{Metallurgical properties of iron ores for experiments Experimental procedures}

\section{Thermal cracking}

The thermal cracking propensity of the iron ores was measured

by a thermal impact method according to ISO 8371:2007 (ISO, 2017). The lump ore samples were crushed and sieved to a grain size of 20-25 mm before use, whereas a size of $12.5-16 \mathrm{~mm}$ was selected for the CVRD pellet experiments, which were conducted by using the static loading reduction equipment in Figure 2 . The adhesive powder on the particles was brushed off with water, and then the large-size iron ores were dried in an oven at $373 \pm 5 \mathrm{~K}$ for 12 hours. The reactor tube was heated from room temperature to $773 \mathrm{~K}, 873 \mathrm{~K}, 973 \mathrm{~K}$, and $1073 \mathrm{~K}$, respectively. Then, the samples were placed into a tube with a $\mathrm{N}_{2}$ gas flow of $15 \mathrm{~L} / \mathrm{min}$. After a 30-minute holding time, the heating and $\mathrm{N}_{2}$ gas flow were interrupted to cool the samples to room temperature.

To study the thermal cracking properties of the iron ore samples, the decrepitation indices $\mathrm{DI}_{-10}, \mathrm{DI}_{-6.3}$, and $\mathrm{DI}_{-3.15}$ were calculated by using the following equations (ISO, 2017):

$$
\begin{aligned}
& D I_{-10}=\frac{W_{1}}{W_{0}} \times 100 \% \\
& D I_{-6.3}=\frac{W_{2}}{W_{0}} \times 100 \% \\
& D I_{-3.15}=\frac{W_{3}}{W_{0}} \times 100 \%
\end{aligned}
$$

\section{Table IV}

Proportions of adhesive powder in the iron ore samples

\begin{tabular}{|l|c|c|c|c|c|}
\hline Sample & L1 & L2 & L3 & Sishen & CVRD \\
\hline PAP (wt\%) & 8.11 & 5.02 & 0.52 & 4.13 & 1.91 \\
\hline
\end{tabular}

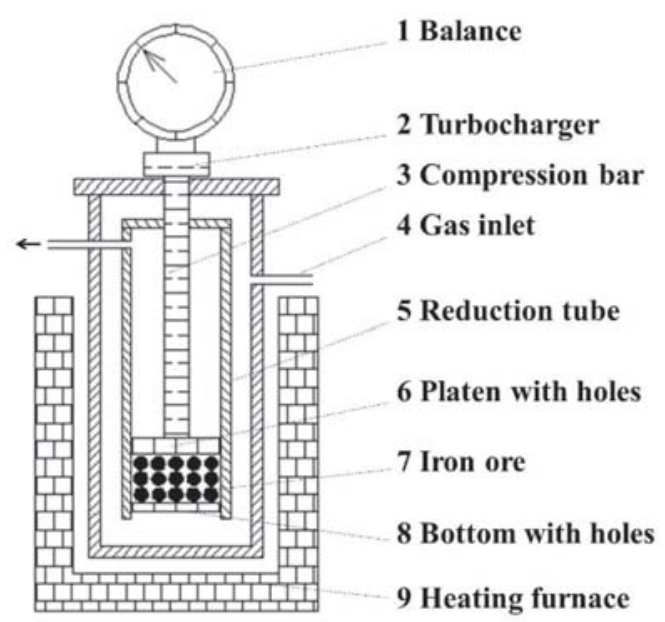

Figure 2-Diagram of static loading reduction equipment 


\section{Optimization of iron ore blending in the COREX shaft furnace}

where $W_{0}$ is the mass of the iron ore samples after heating at 773 $\mathrm{K}, 873 \mathrm{~K}, 973 \mathrm{~K}$, and $1073 \mathrm{~K}$, and $W_{1}, W_{2}$, and $W_{3}$ are the masses of particles that are smaller than $10 \mathrm{~mm}, 6.3 \mathrm{~mm}$, and $3.15 \mathrm{~mm}$, respectively.

\section{Reducibility and reduction degradation}

In the improved evaluation system for iron ores, as was done in the reduction test (Qiu et al., 2017, Li et al., 2016; Standardization Administration of the PR China, 2017, 2016; Li, 2008; Wu, Xu, and Zhang, 2008), lump ore samples were heated from room temperature to $1123 \mathrm{~K}$ under $\mathrm{N}_{2}$ gas at a flow rate of 3 $\mathrm{L} / \mathrm{min}$. Reducing gas with a composition of $68 \% \mathrm{CO}, 9 \% \mathrm{CO}_{2}$, and $23 \% \mathrm{H}_{2}$ was injected into the tube and the samples were reduced for 2 hours. After the reduction, the gas was changed to $\mathrm{N}_{2}$ to cool the samples to room temperature. Reduction test procedures in the improved evaluation system are shown in Figure 3. Based on the standard GB/T13241-2017 (Standarization Administration of the PR China, 2017), the reduction products were weighed to calculate the reduction degree $R$ and metallization rate $M$ as follows (Standardization Administration of the People's Republic of China, 2017):

$$
\begin{aligned}
& R=\frac{m_{0}-m_{R}-m_{L O I}}{m_{0} \times\left[0.43 \times\left(w_{(F e)}-0.11 \times w_{(F e O)}\right)\right]} \times 10^{4} \\
& M=100-\frac{1.5}{1.05}(100-R)
\end{aligned}
$$

where $m_{0}$ and $m_{R}$ represent the initial mass of the iron ore sample before and after reduction at room temperature, respectively, $m_{\text {LOI }}$ represents the loss on ignition, $w_{(F e)}$ indicates the total iron content in the sample, and $w_{(\mathrm{FeO})}$ indicates the FeO content, which was obtained from the ferrous iron content as calculated from Equation [7]. The mass of $\mathrm{Fe}^{2+}$ was measured by the method proposed in the national standard GB/T 6730.8-2016 (Standardization Administration of the PR China, 2016).

$$
w_{(\mathrm{FeO})}=\frac{56+16}{56} \cdot w\left(F e^{2+}\right)=1.286 \cdot w\left(F e^{2+}\right)[7]
$$

The procedures for the reduction degradation test were similar to those for the reduction test, except that the experimental temperature was $823 \mathrm{~K}$ and the composition of the reducing gas was $46 \% \mathrm{CO}, 36 \% \mathrm{CO}_{2}$, and $18 \% \mathrm{H}_{2}$. After cooling to room temperature under $\mathrm{N}_{2}$ gas, the samples were tested in a tumbling drum (130 $\mathrm{mm}$ diameter, $800 \mathrm{~mm}$ height) at a rotation speed of $30 \mathrm{r} / \mathrm{min}$ for 30 minutes. The samples were then sieved at $6.3 \mathrm{~mm}, 3.15 \mathrm{~mm}$, and $0.5 \mathrm{~mm}$ mesh to determine the particle size distribution.

\section{Bonding property}

The procedures for the bonding property test were similar to those of the reduction test, except for an applied load of $0.1 \mathrm{MPa}$ (Li, 2008; $\mathrm{Wu}, \mathrm{Xu}$, and Zhang, 2008). In this experiment, the degree of reduction and volume shrinkage were measured, which are important for determining the bonding characteristics of the iron ore. The bonding index SI was used as an indicator of the bonding property of iron ores as calculated from the following equation:

$$
S I=\frac{m_{1}}{m_{R}} \times 100 \%
$$

where $m_{R}$ represents the sample mass after reduction, and $m_{1}$ is the mass of particles that are larger than $12.5 \mathrm{~mm}$ after the drum test.

The volume shrinkage $V I_{E}$ was determined from the height of the burden before and after reduction, as shown in the following equation (Li, 2008; Wu, Xu, and Zhang, 2008):

$$
V I_{E}=\frac{h_{0}-h_{E}}{h_{0}} \times 100 \%
$$

where $h_{0}$ and $h_{E}$ represent the height of the burden before and after reduction, respectively.

\section{Results}

Figure 4 shows the experimental results for the thermal cracking property of the iron ore samples. No thermal cracking occurred in the CVRD pellets at the experimental temperatures because of their low degree of hydration during induration. With an increase in temperature, the thermal cracking indices, including $D I_{-10}, D I_{-6.3}$, and $D I_{-3.15}$ showed an upward tendency for all lump ores. Compared with Sishen lump ore, L1 and L2 lump ores were considered to have higher thermal cracking indices according to the experimental results at various temperatures, especially the L2 lump ore, whereas the thermal cracking indices of the L3 lump ore were lower.

Figure 5 shows the degree of reduction and metallization rate of the samples after the reduction test at $1123 \mathrm{~K}$. The degree of reduction and metallization rate of the CVRD pellets reached $91 \%$ and $87 \%$, respectively, which were higher than the values for all the lump ores. The results indicate that the reduction degrees and metallization rates of the alternative lump ores L1, L2, and L3 were superior to, or at least similar to, those of Sishen lump ore in the improved reduction test at $1123 \mathrm{~K}$. A probable explanation for this is that the mineral phases and pore structure affect the reduction properties of the iron ores. In this study, the dominant

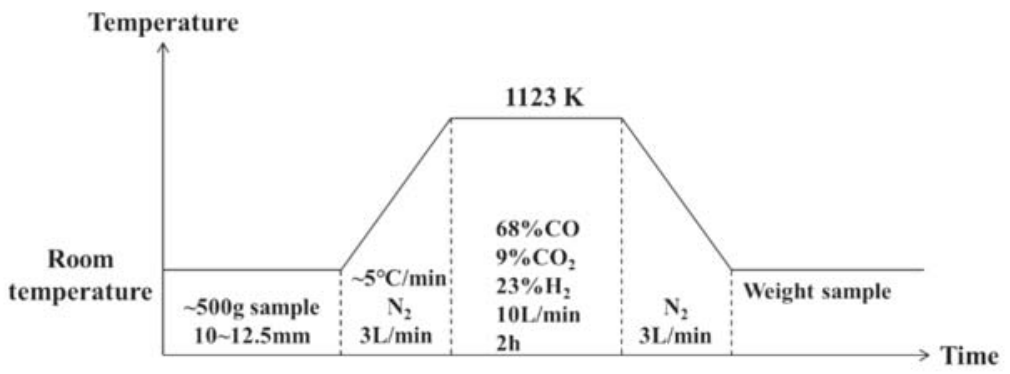

Figure 3-Reduction test procedures in the improved evaluation system 


\section{Optimization of iron ore blending in the COREX shaft furnace}

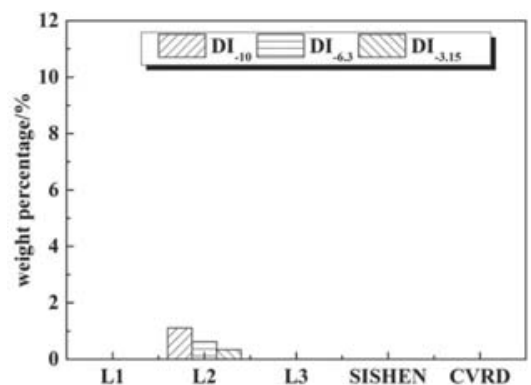

(a)

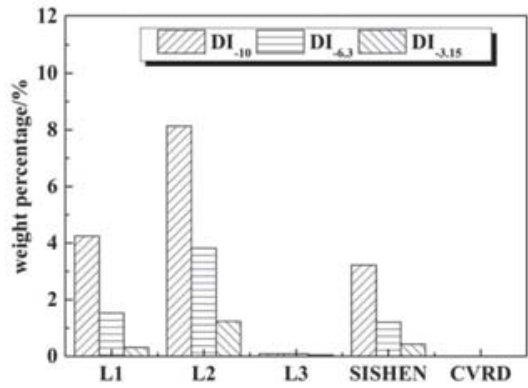

(c)

Figure 4-Thermal cracking test results: (a) $773 \mathrm{~K}$, (b) $873 \mathrm{~K}$, (c) $973 \mathrm{~K}$, (d) $1073 \mathrm{~K}$

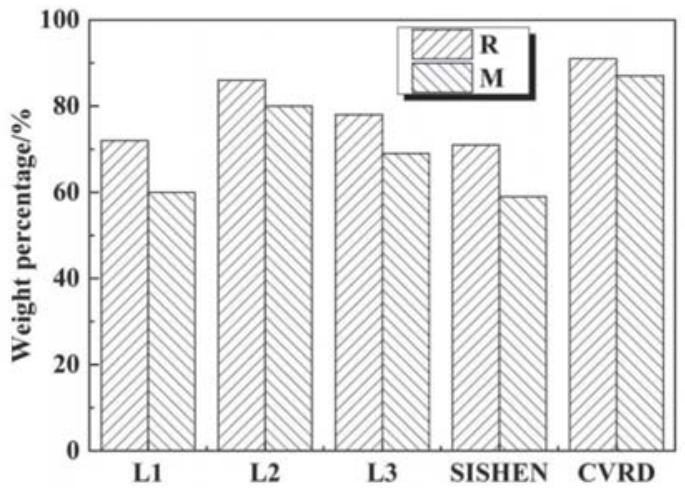

Figure 5-Reduction degree and metallization rate of iron ores at $1123 \mathrm{~K}$

phase in all the iron ores was haematite. Actually, with the increase in the amount of open pores in the ores, the reducing gas can permeate the particles more easily and the interfacial areas between the ore and reducing gas increases, which could promote the reduction reactions and improve the reduction degree and metallization rate of the ores (Wu et al., 2011). Based on the results shown in Figure 5, it is suggested that the apparent porosities of L1, L2, and L3 lump ores are higher than that of Sishen lump ore, but lower than that of CVRD pellets.

Figure 6 shows the degree of reduction and reduction degradation behaviour of the iron ore samples at $823 \mathrm{~K}$. After reduction, L2 lump ore has the highest mass ratio of particles smaller than $0.5 \mathrm{~mm}$ and smaller than $3.15 \mathrm{~mm}$, which means that the degradation behaviour of L2 lump ore was the most severe. The $\mathrm{RDI}_{-0.5}$ of the L1 and L3 lump ores was close to that of the Sishen lump ore. The CVRD pellets had a higher $\mathrm{RDI}_{-0.5}$, despite the RDI ${ }_{-3.15}$ being lower. Previous work has shown that the basic reason for the reduction degradation of iron ore is that, during the reduction of $\mathrm{Fe}_{2} \mathrm{O}_{3}$ at low temperature (673-873 K),

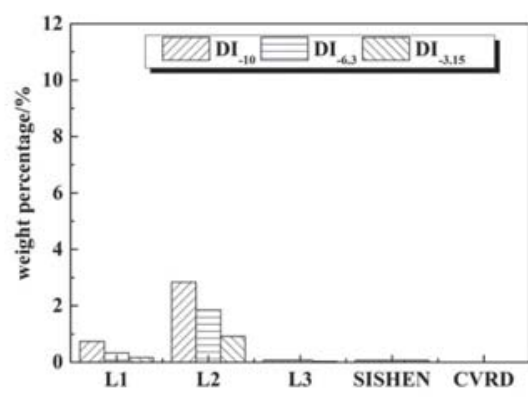

(b)

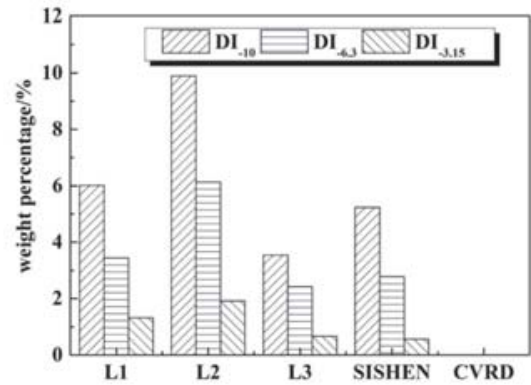

(d)

the transformation of haematite to magnetite causes crystal lattice deformation and an increase in internal stress, which contributes to the degradation of the ore $\mathrm{Wu}$ et al., 2017).

Figure 7 shows the bonding index, volume shrinkage, and degree of reduction of iron ore samples after the bonding property test. A marked bonding propensity would impair the reduction. In general, as shown in Figure 7, Sishen lump ore has the highest bonding index among all the samples. The bonding indices of the L2 lump ore and the CVRD pellets were lower than those of the L1 and L3 lump ores. L1, L2, and L3 lump ores exhibited a better bonding performance than the Sishen lump ore.

The bonding index correlated positively with the reduction degree and volume shrinkage of the lump ores For the CVRD pellets, although the reduction degree was high with a large amount of metallic iron, the spherical shape and low volume shrinkage resulted in a point contact with a small bonding area and low bonding strength. Contact between the particles is also a critical factor in the bonding behaviour of iron ores.

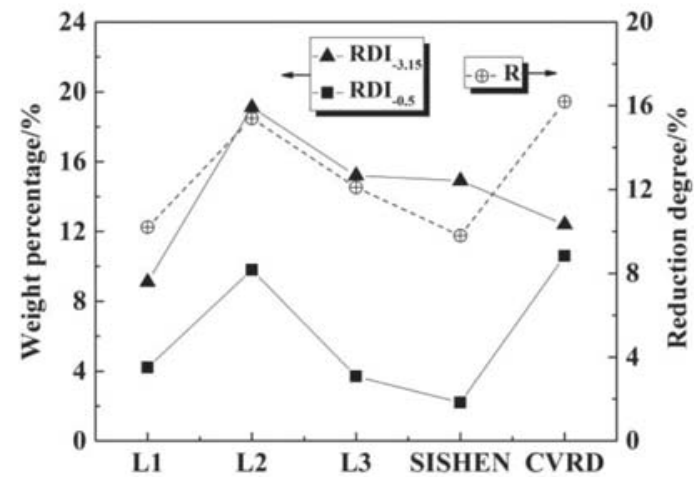

Figure 6-Reduction degree and reduction degradation index of iron ores at $823 \mathrm{~K}$ 


\section{Optimization of iron ore blending in the COREX shaft furnace}

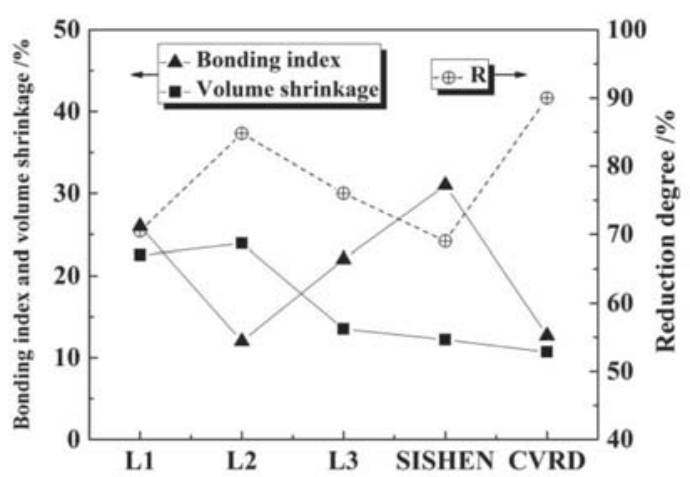

Figure 7-Bonding index, volume shrinkage, and reduction degree of iron ores at $1123 \mathrm{~K}$

\section{Optimization of iron ore blending in the COREX shaft furnace}

\section{Substitutability of the alternative lump ores}

The substitutability of the alternative lump ores was assessed by comparing the physicochemical and metallurgical properties of the Sishen lump ore and lump ores L1, L2, and L3 using the improved evaluation method.

Compared with the Sishen lump ore, the total Fe, S, and $\mathrm{K}_{2} \mathrm{O}$ contents of the $\mathrm{L} 1$ lump ore were $0.15 \%, 0.012 \%$, and $0.04 \%$ lower, respectively, whereas the P content and loss on ignition (LOI) were higher by $0.022 \%$ and $1.1 \%$, respectively. After brushing, cleaning, and drying, the proportion of adhesive powder in the L1 lump ore was 3.98\% higher than that in the Sishen lump ore. The L1 lump ore size distribution was broader. The thermal cracking at different temperatures, the reduction degree, and the metallization rate at $1123 \mathrm{~K}$ of the $\mathrm{L} 1$ lump ore were very similar to those of the Sishen lump ore, although its $\mathrm{RDI}_{-3.15}$ and bonding index at $823 \mathrm{~K}$ were lower by $3.3 \%$ and $5 \%$, respectively. In general, little difference was found between the Sishen and L1 lump ores in terms of physicochemical properties, thermal cracking propensity, and reduction and reduction degradation behaviour, although the higher bonding index of the L1 lump should be taken into consideration.

The total $\mathrm{Fe}, \mathrm{S}$, and $\mathrm{K}_{2} \mathrm{O}$ contents of the L2 lump ore were lower than those of the Sishen lump ore by $1.36 \%, 0.007 \%$, and $0.036 \%$, respectively, whereas the $\mathrm{P}, \mathrm{Na}_{2} \mathrm{O}$, and LOI were higher by $0.033 \%, 0.002 \%$, and $2.05 \%$, respectively. The proportion of adhesive powder in the L 2 lump ore was also higher than that in the Sishen lump ore by $0.89 \%$. The size distribution of the L2 lump ore was relatively narrow and its average particle size was almost twice that of the Sishen lump ore. As regards drum strength, the $\mathrm{DI}_{-10}, \mathrm{DI}_{-6.3}$, and $\mathrm{DI}_{-3.15}$ of $\mathrm{L} 2$ lump ore at $1073 \mathrm{~K}$ were $9.89 \%, 6.13 \%$, and $1.92 \%$; higher than the Sishen lump ore by $4.66 \%, 3.35 \%$, and $1.36 \%$, respectively. However, at $1123 \mathrm{~K}$, the degree of reduction and metallization rate of L2 lump ore were higher than the values for Sishen lump ore by $15 \%$ and $21 \%$. The bonding index of L2 lump ore was only $12 \%$, compared with $31 \%$ for the Sishen lump ore. So, although the physicochemical properties, thermal cracking propensity, and reduction degradation behaviour of the L2 lump ore were inferior to Sishen lump ore, due to its excellent reduction and bonding properties, L2 lump ore could probably substitute for Sishen lump ore in the COREX ironmaking process. However, the amount of adhesive powder in the L2 lump ore needs to be determined carefully to maintain a smooth COREX operation.

For L3 lump ore, the total Fe, P, and LOI were lower than for the Sishen lump ore by $0.7 \%, 0.022 \%$, and $0.13 \%$, respectively, whereas the $\mathrm{S}, \mathrm{K}_{2} \mathrm{O}$, and $\mathrm{Na}_{2} \mathrm{O}$ contents were higher by $0.003 \%$, $0.13 \%$ and $0.026 \%$, respectively. The proportion of adhesive powder in the L3 lump ore was $0.52 \%$ lower than that of the Sishen lump ore. The size distribution of the L3 lump ore was also relatively narrow and the average size was $6.43 \%$. larger than that of the Sishen lump ore As mentioned previously, the thermal cracking indices of the L3 lump ore were the lowest among the four lump ores at various temperatures. The reduction degree and metallization rate of the L3 lump ore at $1123 \mathrm{~K}$ ore were similar to those of the Sishen lump ore, as well as the reduction degradation at $823 \mathrm{~K}$. The bonding index of the L3 lump ore was lower than that of Sishen lump ore by $9 \%$. So, L3 lump ore is also a reasonable choice for replacing Sishen lump ore in the COREX ironmaking process. However, the excess alkali in L3 lump ore should be avoided.

A rating system was established by using points to comprehensively evaluate the physicochemical and metallurgical properties of Sishen lump ore, CVRD pellets, and L1, L2, and L3 lump ores to study the substitutability. Due to space limitations, only some rating examples are shown in Table V. Besides the points, the weights for the physicochemical properties, thermal cracking propensity, reducibility and reduction degradation, and bonding property are also different, and were artificially set at $15 \%, 15 \%, 45 \%$, and $25 \%$, respectively. A higher point rating represents better comprehensive properties of the iron ore. Evaluation points for the L1, L2, L3, Sishen, and CVRD ores are shown in Figure 8. The comprehensive evaluation scores of the L1, L2, and L3 lump ores were all higher than that of Sishen lump ore, which indicated their substitutability. This was validated in the subsequent industrial experiments. CVRD pellets present the highest evaluation score of 4.24 , as shown in Figure 8.

\section{Table $V$}

Examples in the rating system to evaluate the physicochemical and metallurgical properties of the iron ores

\begin{tabular}{|c|c|c|c|c|c|c|c|c|}
\hline \multicolumn{6}{|c|}{ Physicochemical properties (wt\%) } & \multicolumn{3}{|c|}{ Metallurgical properties } \\
\hline Point & Fe total & $\mathbf{P}$ & $\mathrm{S}$ & $\mathrm{K}_{2} \mathrm{O}$ & $\mathrm{Na}_{2} \mathrm{O}$ & $\mathrm{DI}_{-6.3}$ at $873 \mathrm{~K}$ & Bonding index at $1123 \mathrm{~K}$ & $\mathrm{R}$ at $1123 \mathrm{~K}$ \\
\hline $\begin{array}{l}0 \\
1 \\
2 \\
3 \\
4 \\
5 \\
6\end{array}$ & $\begin{array}{c}<62 \\
62-65 \\
>65\end{array}$ & $\begin{array}{c}>0.08 \\
0.05-0.08 \\
<0.05\end{array}$ & $\begin{array}{c}>0.05 \\
0.03-0.05 \\
<0.03\end{array}$ & $\begin{array}{c}>0.18 \\
0.10-0.18 \\
0.03-0.10 \\
<0.03\end{array}$ & $\begin{array}{c}>0.04 \\
0.02-0.04 \\
<0.02\end{array}$ & $\begin{array}{l}>3 \% \\
2-3 \% \\
1-2 \% \\
0-1 \%\end{array}$ & $\begin{array}{c}25-35 \% \\
15-25 \% \\
5-15 \% \\
<5 \% \\
0\end{array}$ & $\begin{array}{c}50-60 \% \\
60-70 \% \\
70-80 \% \\
80-90 \% \\
>90 \%\end{array}$ \\
\hline
\end{tabular}




\section{Optimization of iron ore blending in the COREX shaft furnace}

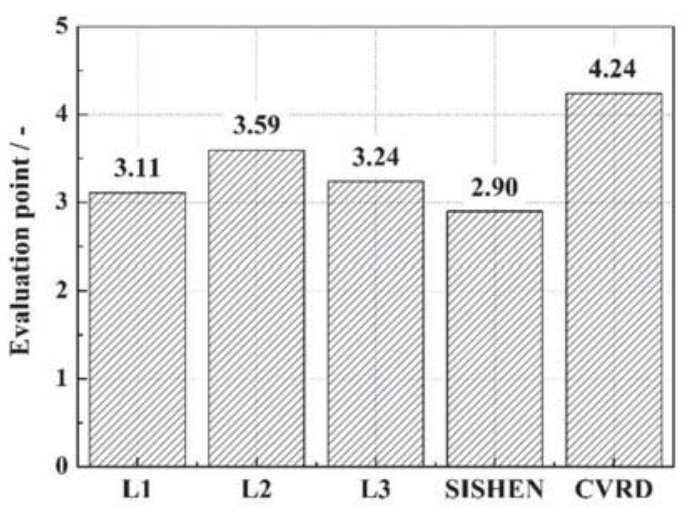

Figure 8-Evaluation scores for the iron ores

\section{Schemes for iron ore blending and simulated industrial experiments}

To improve the reduction performance, inhibit the bonding behaviour of the lump ores, and control the production cost, based on the physicochemical and metallurgical properties of the iron ores in this study, five alternative schemes for optimizing the iron ore blend have been proposed and tested in COREX production experiments. The degree of reduction, metallization rate, and bonding index were measured to evaluate these blending schemes. The experimental procedures are shown in Figure 9. The ore blending schemes are shown in Table VI.

The experimental results are shown in Table VII. Compared with the original scheme, the degree of reduction, metallization rate, and bonding performance of schemes I, II and III were improved, whereas the degree of reduction and metallization rate of schemes IV and V decreased. The improved bonding behaviour was due to the decrease in the proportion CVRD pellets to $50 \%$. The reduction degrees for schemes I, II, and III were higher than $90 \%$ and the metallization rates were higher than $85 \%$, with scheme III the highest. However, the bonding index of scheme III was low. Sishen lump ore could therefore be totally replaced by a blend of L2 and L3 lump ores, as shown in scheme III. The defects of a single variety of iron ore and a high bonding index can be overcome by optimized iron-ore blending. The results confirm the effectiveness of the improved evaluation method for iron ores.

\section{Industrial verification of iron ore blending scheme}

Due to the high metallization rate and low bonding index, blending scheme III was selected to conduct an industrial experiment to verify its effectiveness in COREX production. In order to maintain steady production without sudden changes to the burden structure, the proportion of blended L2 and L3 lump ores (in a 1:1 ratio) was increased progressively. Thus in the industrial trials, 20 and 40 mass\% of Sishen lump ore were replaced by the L 2 and L 3 blend. The experiment results, including metallization rate and hydraulic pressure in the discharge equipment, for one month of production for original the scheme (60\% CVRD, 40\% Sishen), scheme A (60\% CVRD, 20\% Sishen, 20\% blended L2 and L3), and scheme B (60\% CVRD, $40 \%$ blended L2 and L3) are compared in Figure 10. It is shown that as the proportion of blended L2 and L3 increased from zero to $20 \%$ to $40 \%$, the average metallization rate rose from $61.8 \%$ to $65.7 \%$ to $73.5 \%$, indicating the improvement in productivity.

\section{Table VI \\ Ore blending schemes for the simulated COREX production experiments}

\begin{tabular}{|l|c|c|c|c|c|c|}
\hline Scheme & Original & I & II & III & IV & V \\
\hline CVRD & $60 \%$ & $60 \%$ & $60 \%$ & $60 \%$ & $50 \%$ & $50 \%$ \\
Sishen & $40 \%$ & $20 \%$ & - & - & - & - \\
L1 & - & - & $20 \%$ & - & $30 \%$ & - \\
L2 & - & - & - & $20 \%$ & - & $30 \%$ \\
L3 & - & $20 \%$ & $20 \%$ & $20 \%$ & $20 \%$ & $20 \%$ \\
\hline
\end{tabular}

\section{Table VII}

Results for the simulated COREX production experiments

Scheme Reduction degree (\%) Metallization rate (\%) Bonding index (\%)

\begin{tabular}{|l|l|l|l|}
\hline Original & 89.2 & 84.6 & 7.2 \\
I & 90.1 & 85.8 & 6.5 \\
II & 90.2 & 85.9 & 6.1 \\
III & 92.8 & 89.8 & 5.1 \\
IV & 82.5 & 75.0 & 5.6 \\
V & 85.4 & 79.1 & 4.9 \\
\hline
\end{tabular}

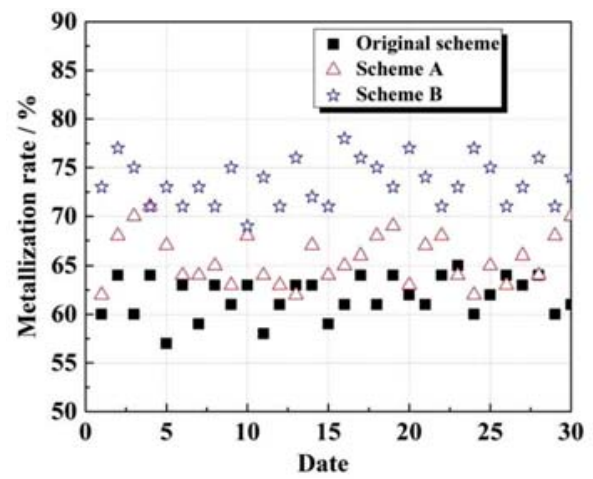

Figure 10-Metallization rates of iron ores in industrial production

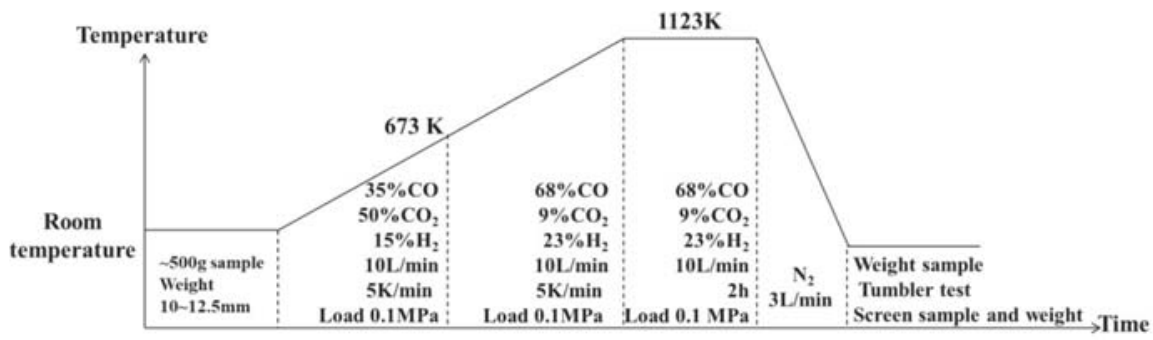

Figure 9-Procedures for simulated COREX production experiments 


\section{Optimization of iron ore blending in the COREX shaft furnace}

Table VIII
Hydraulic pressure of screw equipment in the industrial experiment

\begin{tabular}{|c|c|c|c|c|c|c|c|c|}
\hline \multirow[t]{2}{*}{ Scheme } & \multicolumn{8}{|c|}{ Hydraulic pressure of screw (MPa) } \\
\hline & 1 & 2 & 3 & 4 & 5 & 6 & 7 & 8 \\
\hline $\begin{array}{l}\text { Original scheme } \\
\text { Scheme A } \\
\text { Scheme B }\end{array}$ & $\begin{array}{l}3.11 \\
2.87 \\
2.75\end{array}$ & $\begin{array}{l}2.75 \\
2.71 \\
2.60\end{array}$ & $\begin{array}{l}2.66 \\
2.80 \\
2.60\end{array}$ & $\begin{array}{l}3.10 \\
3.07 \\
2.65\end{array}$ & $\begin{array}{l}3.33 \\
2.69 \\
2.40\end{array}$ & $\begin{array}{l}2.76 \\
2.55 \\
2.39\end{array}$ & $\begin{array}{l}2.70 \\
2.49 \\
2.28\end{array}$ & $\begin{array}{l}2.97 \\
2.71 \\
2.54\end{array}$ \\
\hline
\end{tabular}

Generally, the screw load in the lower part of the shaft furnace increases with the gradual bonding of the burden (Li et al., 2013; Hou et al., 2014). The average hydraulic pressure of each screw for one month in this study is shown in Table VIII. The hydraulic pressure decreased as the proportion of blended L2 and L3 increased, indicating that the bonding behaviour was inhibited, which benefited smooth production and reduced the amount of clean-up required. Both the production efficiency and safety were greatly improved. The laboratory and industrial experiments proved that blended L2 and L3 lump ores could effectively replace Sishen lump ore, which accounted for $40 \%$ of the burden weight, and be used in combination with CVRD pellets in COREX production.

\section{Conclusions}

> In line with the conditions of industrial-scale COREX production, the highest experimental temperature, reduction time, and gas flow rate in the original evaluation system were modified to 1073-1173 K, 2 hours for reduction,, and $20 \mathrm{~L} / \mathrm{min}$ per kilogram of iron ore, respectively. The amount of adhesive ore powder, low-temperature reduction degradation, and the thermal cracking propensity were included in the evaluation system.

> Thermal cracking indices $\mathrm{DI}_{-10}, \mathrm{DI}_{-6.3 .}$, and $\mathrm{DI}_{-3.15}$ of all lump ores increased with increasing experimental temperature, with those of the L3 lump ore being the lowest at various temperatures.

> The reducibility and bonding behaviour of all the alternative lump ores were better than or similar to those of Sishen lump ore. The $\mathrm{RDI}_{-3.15}$ of $\mathrm{L} 1$ was markedly lower, and the $\mathrm{RDI}_{-3.15}$ of L3 was similar to that of Sishen lump ore. The $\mathrm{RDI}_{-0.5}$ and $\mathrm{RDI}_{-3.15}$ of L2 were higher than those of the Sishen lump ore, whereas the bonding behaviour of L2 was much better than that of the Sishen lump ore.

> Based on a comprehensive consideration of the three alternative lump ores, five new schemes for iron ore blending were tested under conditions simulating industrial-scale production. The results showed that the reducibility and bonding behaviour of blending ore could be improved by substituting Sishen ore with an alternative lump ore, especially by a blend of L2 and L3, without altering the proportion of CVRD pellets. The substitutability of the new lump ore blend and the effectiveness of the improved evaluation method for iron ores in the COREX process were verified in an industrial test.

> Compared with the original blending scheme, the metallization rate and the bonding behaviour were improved with increasing proportions of blended L2 and L3 lump ore from zero to $20 \%$ and $40 \%$ in the industrial trials.

\section{Acknowledgements}

This work was supported by the National Natural Science
Foundation of China under Grant nos. 51604201 and 51774217, and the scholarship from China Scholarship Council (CSC) under the Grant CSC no. 201708420228. We also thank Liwen Bianji, Edanz Group China (www.liwenbianji.cn/ac) for editing the English text of a draft of this manuscript.

\section{References}

Eвerle, A., SiuKA, D., and Boнm, C. 2006. New Corex C-3000 plant for Baosteel and status of the Corex technology. Stahl Und Eisen, vol. 126, no. 3. pp. 31-39.

Hou, Q.F., Samman, M., Li, J., and Yu, A.B. 2014. Modeling the gas-solid flow in the reduction shaft of COREX. ISIJ International, vol. 54, no. 8. pp. 1772-1780.

INTERNATIONAL ORGANIZATION FOR STANDARDIZATION (ISO). 2017. ISO 8371-2007. Iron ores for blast furnace feedstocks - Determination of the decrepitation index. Geneva.

KANG, T., GuPTA, S., AND SAHAJWALLA, V. 2007. Characterizing swelling behaviour of iron oxides during solid state reduction for COREX application and their implications on fines generation. ISIJ International, vol. 47, no. 11. pp. $1590-1598$

Kumar, P.P., Barman, S.C., Reddy, B.M., and SEKHAR, V.R. 2009. Raw materials for Corex and their influence on furnace performance. Ironmaking \&. Steelmaking, vol. 36, no. 2. pp. 87-90.

KuRunov, I.F. 2010. The direct production of iron and alternatives to the blast furnace in iron metallurgy for the 21st century. Metallurgist, vol. 54, no. 5-6. pp. 335-342.

Li, H.F., Zhou, H., Zhang, T., You, Y., Zou, Z.S., and Xu, W.R. 2016. Influence of screw design on burden descending velocity and particle segregation in COREX shaft furnace. Journal of Iron and Steel Research International, vol. 23, no. 6. pp. 516-524.

LI, Q., Feng, M.X., and Zou, Z.S. 2013. Validation and calibration approach for discrete element simulation of burden charging in pre-reduction shaft furnace of COREX process. ISIJ International, vol. 53, no. 8. pp. 1365-1371.

LI, W.G. 2008. Operation status quo and technology problems of COREX-3000. Proceedings of the Baosteel Biennial Academic Conference 2008, Bac. pp. A-75-83.

Qiv, Z.L., Luo, Z.G., Zhou, H., Chen, R., Wang, F., and Zou, Z.S. 2017. Effect of screw casing structure on descending of burdens in COREX shaft furnace. Journal of Iron and Steel Research International, vol. 24, no. 1. pp. 18-26.

Song, H., Lv, X.P., and Yin, X.P. 2015. Analysis of sponge iron carburization behavior in COREX pre-reduction shaft furnace. Research on Iron \& Steel, vol. 43, no. 5. pp. 9-11.

Standardization Administration of the People's Republic of China. 2017. GB/T132412017, Iron ores - Determination of reducibility.

Standardization Administration of the People's Republic of China. 2016. GB/T 6730.82016, Iron ores - Determination of iron (II) content - Potassium dichromate 2016, Iron ores - Dete
titrimetric method.

Umadevi, T., Kumar, P., Lobo, F.N., Prabhu, M., Mahapatra, P.C., and Ranjan, M. 2011. Influence of pellet basicity (CaO/SiO2) on iron ore pellet properties and microstructure. ISIJ International, vol. 51, no. 1. pp. 14-20.

Wu, S.L., Xu, H.F., and ZHANG, Q. 2008. Study on the characteristics in shaft furnace of Corex-3000 process. Proceedings of the Baosteel Biennial Academic Conference 2008, A-102-107.

Wu, S.L., WAnG, L.X., Kou, M.Y., WAng, Y.J., and Zhang, J.C. 2017. Analysis of operational parameters affecting the sulfur content in hot metal of the COREX process. Metallurgical and Materials Transactions B, vol. 48, no. 1 . process. Metallur $276-285$.

Wu, S.L., Liu, X.Q., Zhou, Q., Xu, J., and Liu, C.S. 2011. Low temperature reduction degradation characteristics of sinter, pellet and lump ore. Journal of Iron and Steel Research International, vol. 18, no. 8. pp. 20-24.

Xu, J., Wu, S.L., Kou, M.Y., and Du, K.P. 2013. Numerical analysis of the characteristics inside pre-reduction shaft furnace and its operation parameters optimization by using a three-dimensional full scale mathematical model. ISIj International, vol. 53, no. 4. pp. 576-582.

Xu, R.S., Zhang, J.L., Wang, G.W.W., Zuo, H.B., Li, P.C., Wang, H.Y., Lin, H., and Liu, S.Y. 2016. Isothermal kinetic analysis on fast pyrolysis of lump coal used in COREX process. Journal of Thermal Analysis and Calorimetry, vol. 123, no. 1. pp. s773-783.

You, Y., Luo, Z.G., Hou, Q.F., Li, H.F., Zhou, H., Chen, R., and Zou, Z.S. 2017. Experimental study of burden distribution in the COREX melter gasifier. Steel Research International, vol. 88, no. 12. https://onlinelibrary.wiley.com/doi/ epdf/10.1002/srin.201700025.

Zhou, H., Wu, S.L., Kou, M.Y., TANG, B., Cheng, H.C., ZHAng, Y.L., and SHen, Y.S. 2017. Solid flow in a shaft furnace in smelting reduction process under circumferential imbalance conditions. Steel Research International, vol. 88, no.

ZHou, H., Luo, Z.G., Zou, Z.S., Zhang, T., and You, Y. 2015. Experimental study on burden descending behavior in COREX shaft furnace with AGD beams. Steel Research International, vol. 86, no. 9. pp. 1073-1081.

Zhou, X.L. and Du, Z.N. 2013. The introduction of COREX process development. Advances in Materials Research, no. 774-776. pp. 1430-1433. 